\title{
THE EFFECT OF USING SURVEY QUESTIONS READ RECITE REVIEW (SQ3R) LEARNING MODEL FOR LEARNING OUTCOMES IN MATHEMATICS STUDENTS OF SMP N 2 PLERET
}

\author{
Ika Putri Astriyana Sari ${ }^{a}$, Suparman $^{\mathrm{b}}$ \\ Program Studi Pendidikan Matematika Universitas Ahmad Dahlan \\ Jalan Ring Road Selatan, Tamanan, Banguntapan, Bantul Yogyakarta \\ ayp19september@gmail.com, ${ }^{\mathrm{b}}$ suparmancict@ yahoo.co.id
}

\begin{abstract}
This research was conducted on the ground of the learnings are applied during this tends to be teacher's centered, many students who are less active, less enthusiastic in learning process. Therefore, it needs a learning model that involves many students makes a student more active. This research aims to determine the influence of the survey questions read recite review (SQ3R) learning model toward mathematics learning outcomes in class VIII of even semester in SMP N 2 PLERET of academic year 2015/2016. The populations in this research were students of class VIII A, B, C, D, E, F, G SMP N 2 Pleret. Samples were taken using random sampling techniques derived from class VIII G as an experimental class and class VIII A as the control class. The data collection method used was the test method. Testing instrument using validity test, remainder test, and reliability test. Data were analyzed using a prerequisite analysis test including normality test using Chi-Square formula, homogeneity test by test Bartlett, and hypothesis test with t-test. Based on calculations at the significant level $\alpha=5 \%$ and 63 degrees of freedom, we conclude that : (1) there is a different result of math study that using Survey Questions Read Recite Review (SQ3R) method and conventional. This is indicated by the result of the first test of the hypothesis that $t_{\text {count }}=2,434>t_{\text {table }}=1.998$. (2)learning using Survey Questions Read Recite Review (SQ3R) learning model is more effective than learning using conventional. It is shown on the second test of the hypothesis that the test result $t_{\text {count }}=$ $2.434>t_{\text {table }}=1.669$.
\end{abstract}

Keywords: Influence, Survey Questions Read Recite Review (SQ3R) learning model, Mathematics Learning Outcomes.

\section{INTRODUCTION}

Education is essentially a conscious effort to improve human personality and abilities both inside and outside of school. Education for humans is an absolute necessity that must be fulfilled for a lifetime. Without taking any education at all, it is impossible for every human being to live and develop in accordance with the ideals that become their way of life. Therefore, to realize human ideals in enhancing personality, developing the ability of attitudes and other forms of behavior, it is necessary to have a professional teacher. In-Law Number 14 of 2005 concerning teachers and lecturers quoted by Soemantri Brodjonegoro, S (2012: 3) stated that: Teachers are professional educators with the main task of educating, teaching, guiding, directing, training, evaluating, evaluating students at early childhood education formal education, basic education, and secondary education. Only teachers who have high professionals are able to carry out this difficult task, teachers are required not only to be a teacher but also as an educator.

Mathematics subjects at various school levels have the aim that students are able to understand mathematical concepts, solve problems related to mathematics, able to communicate ideas in the form of symbols, diagrams, tables or other media in clarifying a problem in various circumstances. Learning model becomes one of the factors that can determine success in the learning process, the use of learning models in class is needed to provide a different atmosphere to students when learning, so as to foster student enthusiasm in teaching and learning activities in class. Researchers conducted observations at SMP Negeri 2 Pleret, a school located in Kedaton Pleret Bantul 55791 Yogyakarta. Observations were made on 7 October 2015 directly at 08.00 - 9.30 WIB by mathematics teacher VIII grade Mrs. Ratna Ruwaida Noor in the teacher room of SMP N 2 Pleret and by students during the break. Learning taking place at SMP N 2 Pleret still applies the Education Unit Level Curriculum (KTSP). 
The SQ3R learning model can be applied in mathematics learning which previously only used conventional learning models because the conventional learning model was not able to invite all students to be active in the teaching and learning process, so the learning outcomes obtained by students were still low and not optimal. Of the 7 classes in the school, namely classes VIII A, B, C, D, E, F, and $\mathrm{G}$, it can be shown that student learning outcomes are still low. The low learning outcomes can be seen from the average value of all classes that are still far from the Minimum Mastery Criteria (KKM). The KKM determined at SMP Negeri 2 Pleret is 70. Many students whose grades have not yet reached KKM, where the average value of students who have not reached KKM there is $96.35 \%$. Table 1 presents a summary of the grades for the Middle Semester Class VIII Even Semester SMP Negeri 2 Pleret in the academic year 2015/2016.

Table 1. Summary of Grades for Midterm Even Semester SMP Negeri 2 Pleret Mathematics Subjects for the 2015/2016 Academic Year

\begin{tabular}{|c|c|c|c|c|c|c|}
\hline Class & VIII A & VIII B & VIII C & VIII D & VIII E & VIII F \\
\hline Average & 47.19 & 49.31 & 51.84 & 43.71 & 44.39 & 38.84 \\
\hline The highest score & 67.50 & 70.00 & 76.00 & 62.50 & 75.00 & 67.50 \\
\hline Lowest value & 25.00 & 32.50 & 40.00 & 17.50 & 25.00 & 17.50 \\
\hline$\geq 70$ & $0 \%$ & $6.90 \%$ & $6.45 \%$ & $0 \%$ & $9.09 \%$ & $0 \%$ \\
\hline$<70$ & $100 \%$ & $93.10 \%$ & $93.55 \%$ & $100 \%$ & $90.91 \%$ & $100 \%$ \\
\hline
\end{tabular}

Source: SMP N 2 Pleret

The results of interviews between researchers and mathematics teachers in grade VIII of SMP Negeri 2 Pleret concluded that the teacher's knowledge of various learning models was still lacking so that it became one of the obstacles to making students like mathematics, assuming that mathematics was a boring subject very difficult. The SQ3R learning model has never been implemented in that school. To improve the learning outcomes of students of class VIII at SMP Negeri 2 Pleret, it is necessary to change active learning processes such as increasing student reading activities. This change can be done by the teacher. Teachers must be creative in using a variety of learning models that invite students to play an active role in learning. The learning model must also be adapted to the subject matter so that learning objectives can be achieved and learning outcomes can be improved.

The Survey Questions Read Recite Review (SQ3R) Learning Model is one part of the elaboration strategy, which uses it to shape students' habits of concentration in reading, practice speed reading skills, practice forecasting skills regarding reading content and develop critical and comprehensive reading skills (Hamzah and Nurdin Mohamad, 2011: 115).

In the learning model Survey Questions, Read Recite Review (SQ3R) researchers provide material that contains material about the construction of prisms. The SQ3R learning model begins with reading material provided by researchers and students identifying reading material in terms of titles, subtitles, symbols, or other terms available in the reading material and students are encouraged to prepare pencils, papers, and a tool for making features. Students are asked to make questions - questions from observations. As students read, they must look for answers to the questions they have made. After reading, making questions, and answering questions they made according to the material, they revealed the answers to the questions they made. In the last stage, students are asked to make conclusions.

From the existing problems, the researcher is motivated to conduct research that focuses on the use of the Survey Questions Read Recite Review (SQ3R) learning model in mathematics learning in the classroom, then see if the learning model is better than the direct learning model towards the mathematics learning outcomes of Class students VIII Even Semester of SMP Negeri 2 Pleret. In this research, the researcher took the title "The Effect of Using Survey Questions Read Recite Review (SQ3R) Learning Model against Student Learning Outcomes of Class VIII Even Semester of SMP Negeri 2 Pleret 2015/2016 Academic Year".

Based on the background of the problem, then the problem can be formulated to be examined as follows: 
1. Is there a significant difference between mathematics learning outcomes using the Survey Questions Read Recite Review (SQ3R) Learning Model and those using conventional learning models for VIII grade students of the Second Semester of SMP Negeri 2 Pleret 2015/2016 Academic Year?

2. Are the results of learning mathematics using the Survey Questions Read Recite Review (SQ3R) Learning Model better than the results of learning mathematics using conventional learning models in class VIII Even Semester SMP Negeri 2 Pleret 2015/2016 Academic Year?

In connection with the problem formulation that has been described, the objectives of this research are:

1. To find out there are significant differences between the results of learning mathematics using the Survey Questions Read Recite Review (SQ3R) Learning Model and those using conventional learning models.

2. To find out which learning outcomes are better between mathematics learning outcomes using the Survey Questions Read Recite Review (SQ3R) Learning Model and those using conventional learning models.

\section{METHODS}

This research is classified as quantitative research. This type of research is experimental research. The experimental design model used is a control group experiment with pretest and posttest design control group design. In the form of a pretest and posttest control group design, both the experimental group and the control group were subject to $\mathrm{O} 1$ and $\mathrm{O} 2$, but only the experimental group received $\mathrm{X}$ treatment, so the design structure is as follows.

Experiment Group: $\mathrm{O} 1 \quad \mathrm{X} \quad \mathrm{O} 2$

Control group : $\mathrm{O} 1 \quad \mathrm{O} 2$

This research was conducted at SMP N 2 Pleret in the middle of the even semester of the academic year 2015/2016.

According to Arifin, Zainal (2012: 215) Population or universe is the whole object under study, whether in the form of people, objects, events, values or things that happen. The population referred to in this study were all students of class VIII SMP N 2 Pleret consisting of 7 namely classes VIII A, VIII B, VIII C, VIII D, VIII E, VIII F, VIII G, all homogeneous classes because they were arranged randomly.

According to Arifin, Zainal (2012: 215) "Samples are a portion of the population to be investigated". In this study samples were taken at random, using random sampling techniques to the class. This sample was taken by lottery class, obtained class VIII G with 32 students used as the experimental class, class VIII A with 33 students used as the control class and class VIII B with 29 students who were used as class trials. The types of variables used in this study are the learning approach and mathematics learning outcomes. The research method is the method used by researchers in gathering research. Variations of the methods referred to are questionnaires, interviews, observations or observations, tests and documentation (Arikunto, Suharsimi., 2010: 203). In this study, research methods in the form of tests were chosen. Understanding the test stated Amier Daien Indrakusuma cited by Arikunto, Suharsimi (1987: 29) The test is a tool or procedure that is systematic and objective to obtain data - data or information desired from someone, in a way that can be said to be precise and fast. The instrument used in this study was a pretest test to determine the initial ability and posttest to determine student learning outcomes. Analysis of the data used in this study was a prerequisite test consisting of a normality test using the Chi-Squared formula, a homogeneity test with a Bartlett test, and a hypothesis test with a t-test. The first hypothesis test is used to find out the hypothesis that there is a significant difference between student learning outcomes in mathematics using the Survey Questions Read Recite Review (SQ3R) learning model and those using conventional learning models. The second hypothesis test used for the use of the Survey Questions Read Recite Review (SQ3R) learning model is better than using conventional learning models. 


\section{RESULTS AND DISCUSSION}

Based on the research that has been carried out obtained data in the form of initial abilities and student learning outcomes.

\section{Initial Ability}

The initial ability score was obtained from the results of the pretest grades of Class VIII A and VIII G from the results of tests conducted by mathematics teachers in class VIII of SMP N 2 Pleret. A summary of the initial mathematical ability scores of the experimental class and the control class can be seen in Table 2 .

Table 2. Summary Descriptions of Initial Ability Values

\begin{tabular}{|l|c|c|}
\hline \multicolumn{1}{|c|}{ Class } & $\begin{array}{c}\text { Experiment } \\
\text { (VIII G) }\end{array}$ & $\begin{array}{c}\text { Control } \\
\text { (VIIIA) }\end{array}$ \\
\hline The highest score & 73.33 & 80 \\
\hline Lowest value & 20 & 26.67 \\
\hline Average & 46.250 & 43.636 \\
\hline S & 13.000 & 15.192 \\
\hline$S^{2}$ & 168.996 & 230.808 \\
\hline \multicolumn{1}{|c|}{ Lots of data } & 32 & 31 \\
\hline
\end{tabular}

Source: SMP N 2 Pleret

The normality test is used to find out whether or not the normal distribution of the initial ability of each experimental class and dick data. Researchers performed 2 times the normality test calculation, namely the normality test for the experimental class and for the control class. The summary of the results of the initial ability normality test can be seen in Table 3 .

Table 3. Summary of Initial Ability Normality Test Results

\begin{tabular}{|c|c|c|}
\hline Variable & $\begin{array}{c}\text { Experiment } \\
\text { (VIII G) }\end{array}$ & $\begin{array}{c}\text { Control } \\
\text { (VIIIA) }\end{array}$ \\
\hline$x^{2}$ & 2.073 & 5.947 \\
\hline$(\alpha)$ & $5 \%$ & $5 \%$ \\
\hline Df $(\mathrm{k}-1)$ & 3 & 4 \\
\hline$x_{\text {table }}^{2}$ & 7.815 & 9.488 \\
\hline Test criteria & \multicolumn{2}{|c|}{$\begin{array}{c}\text { Samples are normally distributed } \\
\text { if } X_{\text {count }}^{2} \leq X_{\text {table }}^{2}\end{array}$} \\
\hline Information & NORMAL & NORMAL \\
\hline
\end{tabular}

From the normality test, the significance level is $5 \%$ and the degree of freedom $=3$, it can be seen that $\chi_{\text {count }}^{2}=2.073$ and $\chi_{\text {table }}^{2}=7.815$ so that $\chi_{\text {count }}^{2}<\chi_{\text {table }}^{2}$, which means that the initial ability scores of the experimental class students were normally distributed. In the control class of 5\% significance level and degree of freedom $=4$, it can be seen that $\chi^{2}{ }_{\text {count }}=5.947$ and $\chi_{\text {table }}^{2}=9.488$, which means the value of the initial ability to control class students is normally distributed.

The homogeneity test on learning outcome data is intended to investigate whether all samples in the population have the same variance or not. Researchers performed homogeneity test calculations 2 times, namely the homogeneity test for the experimental class and for the control class. The summary of the results of the initial ability normality test can be seen in Table 4 . 
Table 4. Summary of Initial Ability Homogeneity Test Results

\begin{tabular}{|c|c|c|}
\hline Variable & $\begin{array}{c}\text { Experiment } \\
\text { (VIII G) }\end{array}$ & $\begin{array}{c}\text { Control } \\
\text { (VIIIA) }\end{array}$ \\
\hline$S_{1}^{2}$ & 168.996 & 230.808 \\
\hline$X_{\text {count }}^{2}$ & \multicolumn{2}{|c|}{0.761} \\
\hline$X_{\text {table }}^{2}$ & \multicolumn{2}{|c|}{3.481} \\
\hline$(\alpha)$ & $5 \%$ & $5 \%$ \\
\hline Df (k-1) & 31 & 32 \\
\hline Test criteria & $\begin{array}{c}\text { Samples are normally distributed if } \\
X_{\text {count }}^{2} \leq X_{\text {table }}^{2}\end{array}$ \\
\hline Information & \multicolumn{2}{|c|}{ HOMOGENEOUS } \\
\hline
\end{tabular}

From the homogeneity test at a significant level of $5 \%$ degrees of freedom $=2$, it can be seen that $\chi_{\text {stat }}^{2}=0.761$ and $\chi^{2}$ table $=3.481$, so that $\chi_{\text {stat }}^{2}<\chi^{2}$ table, which means that both classes have the same variance (homogeneous).

The summary of the initial ability similarity hypothesis test values can be seen in Table 5 .

Table 5. Summary of Initial Ability Hypothesis Test Results

\begin{tabular}{|c|c|c|c|c|}
\hline $\boldsymbol{t}_{\text {stat }}$ & $\boldsymbol{t}_{\text {table }}$ & $\boldsymbol{\alpha}$ & $\mathbf{D k}$ & Information \\
\hline 0.744 & 1.998 & $5 \%$ & 63 & $\begin{array}{c}H_{O} \text { accepted } \\
\mathrm{H}_{1} \text { rejected }\end{array}$ \\
\hline
\end{tabular}

From the similarity hypothesis test at a significant level of 5\% and the degree of freedom $=63$, it can be seen that $t_{\text {count }}=0.744$ and $t_{\text {table }}=1.998$, so that $t_{\text {caount }}<t_{\text {table }}$ which means there is no difference in the value of the initial mathematical ability between the control class and the experimental class in class VIII SMP Negeri 2 Pleret Doctrine 2015/2016 that uses the Survey Questions Read Recite Review (SQ3R) learning model.

\section{Mathematical Learning Outcomes}

The value of student learning outcomes is obtained from the results of the posttest grades VIII A and VIII G from the results of the study and using the stated questions can be used to determine student learning outcomes, the questions consist of 18 questions. Summary of the description of the mathematics learning outcomes of the experimental class and the control class can be seen in Table 6 .

Table 6. Summary of Learning Outcomes Data

\begin{tabular}{|l|c|c|}
\hline \multicolumn{1}{|c|}{ Class } & $\begin{array}{c}\text { Experiment } \\
\text { (VIII G) }\end{array}$ & $\begin{array}{c}\text { Control } \\
\text { (VIIIA) }\end{array}$ \\
\hline $\begin{array}{l}\text { The highest } \\
\text { score }\end{array}$ & 77.78 & 83.33 \\
\hline Lowest value & 38.89 & 33.33 \\
\hline Average & 59.201 & 52.525 \\
\hline S & 9.838 & 12.115 \\
\hline$S^{2}$ & 96.793 & 146.780 \\
\hline Lots of data & 32 & 33 \\
\hline
\end{tabular}

Source: SMP N 2 Pleret

The normality test is used to find out whether or not the normal distribution of the initial ability of each experimental class and dick data. Researchers performed 2 times the normality test calculation, namely the normality test for the experimental class and for the control class. The summary of the results of the initial ability normality test can be seen in Table 7 . 
Table 7. Summary of Test Results on the Normality of Learning Outcomes

\begin{tabular}{|c|c|c|}
\hline Variable & $\begin{array}{c}\text { Experiment } \\
\text { (VIII G) }\end{array}$ & $\begin{array}{c}\text { Control } \\
\text { (VIIIA) }\end{array}$ \\
\hline$x^{2}$ & 3.877 & 3.161 \\
\hline$(\alpha)$ & $5 \%$ & $5 \%$ \\
\hline Df $(\mathrm{k}-1)$ & 3 & 4 \\
\hline$X_{\text {table }}^{2}$ & 7.815 & 9.488 \\
\hline Test criteria & \multicolumn{2}{|c|}{$\begin{array}{c}\text { Samples are normally distributed if } \\
X_{\text {count }}^{2} \leq X_{\text {table }}^{2}\end{array}$} \\
\hline Information & NORMAL & NORMAL \\
\hline
\end{tabular}

From the normality test, the significance level is $5 \%$ and the degree of freedom $=3$, it can be seen that $\chi_{\text {count }}^{2}=3.877$ and $\chi^{2}$ table $=7.815$ so that $\chi_{\text {count }}^{2}<\chi^{2}$ table, which means the learning outcomes of experimental class students are normally distributed. In the control class of $5 \%$ significance level and degree of freedom $=4$, it can be seen that $\chi_{\text {count }}^{2}=3.161$ and $\chi_{\text {table }}^{2}=9.488$, which means the value of the learning outcomes of control class students is normally distributed.

The homogeneity test on learning outcome data is intended to investigate whether all samples in the population have the same variance or not. Researchers performed homogeneity test calculations 2 times, namely the homogeneity test for the experimental class and for the control class. The summary of the results of the initial ability normality test can be seen in Table 8 .

Table 8. Summary of Homogeneity Test Results Learning Outcomes

\begin{tabular}{|c|c|c|}
\hline Variable & $\begin{array}{c}\text { Experiment } \\
\text { (VIII G) }\end{array}$ & $\begin{array}{c}\text { Control } \\
\text { (VIIIA) }\end{array}$ \\
\hline$S_{1}^{2}$ & 96.793 & 146.780 \\
\hline$X_{\text {count }}^{2}$ & \multicolumn{2}{|c|}{1.346} \\
\hline$X_{\text {table }}^{2}$ & \multicolumn{2}{|c|}{3.481} \\
\hline$(\alpha)$ & $5 \%$ & $5 \%$ \\
\hline Df (k-1) & 31 & 32 \\
\hline Test criteria & \multicolumn{2}{|c|}{$\begin{array}{c}\text { Samples are normally distributed if } \\
X_{\text {count }}^{2} \leq X_{\text {table }}^{2}\end{array}$} \\
\hline Information & \multicolumn{2}{|c|}{ HOMOGENEOUS } \\
\hline
\end{tabular}

From the homogeneity test at a significant level of $5 \%$ degrees of freedom $=2$, it can be seen that $\chi_{\text {count }}^{2}=1.346$ and $\chi^{2}$ table $=3.481$, so that $\chi_{\text {count }}^{2}<\chi^{2}$ table, which means that both classes have the same variance (homogeneous).

The summary of hypothesized test scores in terms of learning outcomes can be seen in Tables 9 and 10.

Table 9. Summary of Hypothesis Test Results of Two Parties Learning Outcomes

\begin{tabular}{|c|c|c|c|c|}
\hline $\boldsymbol{t}_{\text {count }}$ & $\boldsymbol{t}_{\text {table }}$ & $\boldsymbol{\alpha}$ & $\mathbf{D f}$ & Information \\
\hline 2.434 & 1.998 & $5 \%$ & 63 & $\begin{array}{c}H_{O} \text { accepted } \\
\mathrm{H}_{1} \text { rejected }\end{array}$ \\
\hline
\end{tabular}

From the similarity hypothesis test at a significant level of 5\% and the degree of freedom $=$ 63 , it can be seen that $t_{\text {count }}=2.434$ and $t_{\text {table }}=1.998$, so that $t_{\text {count }}>t_{\text {table }}$ which means there is a difference in the value of mathematics learning outcomes between the control class and the experimental class in class VIII SMP Negeri 2 Pleret Teaching 2015/2016 that uses the Survey Questions Read Recite Review (SQ3R) learning model with those using conventional learning. 
Table 10. Summary of the Results of the One Party Hypothesis Test Learning Outcomes

\begin{tabular}{|c|c|c|c|c|}
\hline $\boldsymbol{t}_{\text {count }}$ & $\boldsymbol{t}_{\text {table }}$ & $\boldsymbol{\alpha}$ & Df & \multicolumn{1}{|c|}{ Information } \\
\hline 2.434 & 1.998 & $5 \%$ & 63 & $\begin{array}{l}H_{o} \text { accepted } \\
H_{1} \text { rejected }\end{array}$ \\
\hline
\end{tabular}

From the similarity hypothesis test at a significant level of 5\% and the degree of freedom $=63$, it can be seen that $t_{\text {count }}=2.434$ and $t_{\text {table }}=1.669$, so that $t_{\text {count }}>t_{\text {table }}$ which means learning using the Survey Questions Read Recite Review (SQ3R) learning model rather than using conventional learning.

\section{CONCLUSION}

Based on the results of research and discussion as described, several research conclusions can be drawn as follows.

1. There is a significant difference between students' mathematics learning outcomes using the Survey Questions Read Recite Review (SQ3R) learning model and conventional learning models in class VIII students in the even semester of SMP N 2 Pleret in the 2015/2016 academic year. This is indicated by the results of the first hypothesis test wherewith a significant level of $5 \%$ with a degree of freedom 63, then the value $t_{\text {count }}=2,434$ and $t_{\text {table }}=1,998$, which means $t_{\text {count }}>t_{\text {table }}$, because $t_{\text {count }}>t_{\text {table }}, \mathrm{H}_{0}$ is rejected, $\mathrm{H}_{1}$ is accepted.

2. The results of learning mathematics using the Survey Questions Read Recite Review (SQ3R) learning model are better than conventional learning models in class VIII students in the even semester of SMP N 2 Pleret in the academic year 2015/2016. This is indicated by the results of the second hypothesis test wherewith a significant level of $5 \%$ with a degree of freedom 63 , we get the value of $t_{\text {count }}=2,434$ and $t_{\text {table }}=1,669$, which means $t_{\text {count }}>t_{\text {table }}$, because $t_{\text {count }}>$ $t_{\text {table }}$ then $\mathrm{H}_{0}$ is rejected, $\mathrm{H}_{1}$ is accepted.

Based on the above conclusions, then some suggestions that researchers can disclose for are as follows:

1. The learning model Survey Questions Read Recite Review (SQ3R) can be used as an alternative to making the learning process in class more fun and not boring.

2. Students are expected to be able to familiarize themselves with the learning process with the learning model Survey Questions Read Recite Review (SQ3R) or a combination of other learning models other than those generally received in the classroom.

3. Schools are able to facilitate the development and use of learning models and make efforts to improve the ability of teachers to apply learning models.

\section{REFERENCES}

Arifin, Zainal. 2012. Penelitian Pendidikan Metode dan Paradigma Baru. Bandung: PT Remaja Rosdakarya.

Arikunto, Suharsimi.1987. Dasar - Dasar Evaluasi Pendidikan. Jakarta: Bina Aksara. . 2010. Prosedur Penelitian Suatu Pendekatan Praktik. Jakarta: PT Rineka Cipta.

Hamzah dan Nurdin Mohamad. 2011. Belajar dengan Pendekatan Pembelajaran Aktif, Inovatif, Lingkungan, Kreatif, Efektif, Menarik. Jakarta: PT Bumi Aksara.

Soemantri Brodjonegoro, S. 2012. Undang - Undang Guru dan Dosen. Yogyakarta: Pustaka Pelajar. 